\title{
Adaptive Variation in the Level of Oxidative Activity in Saccharomyces cerevisiae
}

\author{
BY C. F. STRITTMATTER \\ Microbiology Unit, Department of Biochemistry, University of Oxford*
}

\begin{abstract}
SUMMARY : After growth in a medium containing $2 \%(\mathrm{w} / \mathrm{v})$ galactose, a strain of Saccharomyces cerevisiae showed greater oxidative activity, an essentially unchanged anaerobic fermentation rate and an increase in total growth, compared with yeast grown in the same medium but containing instead $2 \%(\mathrm{w} / \mathrm{v})$ glucose as major carbon source. The galactose-grown yeast possessed a generally higher level of oxidative metabolism, with enhanced $Q_{0_{2}}^{\text {sir }}$ values (up to $500 \%$ ) with glucose and other oxidizable substrates, a higher cytochrome content and a greatly increased cytochrome oxidase activity. These differences were associated with an inhibitory effect of glucose on the formation of oxidative enzymes when this sugar was present in the growth medium at concentration greater than $0.05 \%(w / v)$. Changes in the composition of the basal growth medium greatly altered the magnitude of the differences between the glucosegrown and galactose-grown organisms and the differences were not apparent with certain growth media. Possible interpretations of these findings are discussed.
\end{abstract}

The adaptation of yeast and other micro-organisms to the utilization of galactose or other saccharides has been widely employed as the test system in studies on the mechanisms of enzymic adaptation (Stephenson \& Yudkin, 1936; Monod, 1942; Spiegelman, 1946). Such adaptations involve the formation of enzymes for the conversion of these sugars into intermediates of glucose or ribose metabolism; the existence of independent routes for metabolism of other sugars has not been clearly demonstrated. Thus, in the adaptive utilization of galactose in yeast a specific galactokinase is formed for conversion of galactose to galactose-1-phosphate (Trucco, Caputto, Leloir \& Mittelman, 1948), and a second adaptive enzyme, galactowaldenase, converts galactose1-phosphate to glucose-1-phosphate (Caputto, Leloir, Cardini \& Paladini, 1950). The glucose-1-phosphate is assumed to be then metabolized by the usual fermentative and oxidative routes of glucose metabolism. Adapted yeast can utilize galactose either oxidatively or fermentatively (Sheffner \& Lindegren, 1952). In growth experiments with Streptococcus pyogenes, White, Steele \& Pierce (1955) observed a partial shift from homolactic metabolism with glucose as carbon source to a heterolactic metabolism with galactose. However, the possibility of the development of alternate pathways or of alterations in the balance of existing metabolic patterns as a result of adaptation appears not to have been thoroughly examined in yeasts.

It therefore seemed of interest to study further the observation made in this laboratory (Dr June Lascelles, personal communication) that after growth on galactose a strain of Saccharomyces cerevisiae oxidized glucose more rapidly

* Present address: Department of Biochemistry, Harvard Medical School, Boston, Massachusetts, U.S.A. 
than did the unadapted yeast grown on the same type of medium but utilizing glucose as major carbon source. The present work was an attempt to define this phenomenon more precisely. A preliminary report of this study has been presented previously (Strittmatter, 1955).

\section{METHODS}

Saccharomyces cerevisiae, strain no. 77 of the National Collection of Yeast Cultures (Brewing Industry Research Foundation, Nutfield, Surrey, England), was used in this work. The organism has been maintained in our laboratory on agar slopes, the medium containing inorganic salts, $2 \cdot 25 \%(w / v)$ Difco malt extract, $0.05 \%(\mathrm{w} / \mathrm{v})$ Difco yeast extract and $0.5 \%(\mathrm{w} / \mathrm{v})$ sucrose.

\section{Preparation of yeast suspensions}

An $18 \mathrm{hr}$. agar slope culture of the organism on the maintenance medium was harvested by centrifugation, washed once with water and resuspended in water to yield a suspension containing the equivalent of $0.3 \mathrm{mg}$. dry wt. organisms $/ \mathrm{ml}$. Samples $(0.3 \mathrm{ml}$.) of this suspension were added to $50 \mathrm{ml}$. samples of liquid growth medium in vessels shaped like an inverted $\mathrm{T}$, similar to those used by Monod, Cohen-Bazire \& Cohn (1951) except that the horizontal limbs of the vessels had a volume of $140 \mathrm{ml}$. Except where otherwise specified, the liquid growth medium contained $17.5 \%(\mathrm{v} / \mathrm{v})$ of a $10 \%(\mathrm{w} / \mathrm{v})$ tryptic digest of casein prepared by the method of Cole \& Onslow $(1916), 0.05 \%(\mathrm{w} / \mathrm{v})$ Marmite (a commercial autolysate of yeast), and either $2 \%(\mathrm{w} / \mathrm{v})$ glucose or $2 \%(\mathrm{w} / \mathrm{v})$ galactose; all growth media were initially adjusted to $\mathrm{pH} 5 \cdot 3$. The vessels were incubated at $30^{\circ}$ and were shaken at 36 oscillations/min. to ensure aeration of the medium. Unless otherwise indicated, the organisms were harvested by centrifugation at equivalent physiological ages, $1 \mathrm{hr}$. before the end of the period of logarithmic growth; this time of harvest ranged from 18 to $40 \mathrm{hr}$., depending upon the medium employed. The organisms were washed three times with cold distilled water $(10 \mathrm{ml} . / 50 \mathrm{ml}$. culture medium) and were resuspended in distilled water immediately before use, unless otherwise indicated. The washed organisms were generally used at once, but might be stored at $2^{\circ}$ for at least 2 days without appreciable change in activity. Culture densities and the dry weight of harvested suspensions were estimated with an EEL photoelectric colorimeter (Evans Electroselenium Ltd.) or a Spekker Absorptiometer (Hilger and Watts Ltd.) which were calibrated for the organism.

\section{Preparation of organisms for assay of cytochrome oxidase}

Heated suspensions (Keilin, 1929). A $2 \%(\mathrm{w} / \mathrm{v})$ suspension of organisms in $0.05 \mathrm{~m}$-phosphate ( $\mathrm{pH} \mathrm{7.1)}$ ) was warmed quickly to $50^{\circ}$ in a water bath, kept at that temperature for $90 \mathrm{~min}$., cooled at $25^{\circ}$ and diluted appropriately for assay.

Cell-free extracts. A $50 \%(\mathrm{w} / \mathrm{v})$ suspension (4 ml.) of the yeast in $0 \cdot 1 \mathrm{M}$-phosphate ( $\mathrm{pH} 7 \cdot 1$ ) was mixed with $10 \mathrm{~g}$. glass balls (Ballotini no. 13) and shaken in 
the Mickle disintegrator (Mickle, 1948) at $2^{\circ}$ until microscopic examination indicated that at least $90 \%$ of the organisms were disrupted. The glass balls, unbroken organisms and cellular debris were removed by centrifugation in the cold, and the opalescent, cell-free supernatant solution used as enzyme preparation.

\section{Manometric determinations}

Rates of oxygen uptake in air $\left(Q_{\mathbf{O}_{2}}^{\mathrm{atr}}\right)$ and of carbon dioxide evolution in nitrogen $\left(Q_{\mathrm{Co}_{\mathbf{g}}}^{\mathbf{N}_{3}}\right)$ were determined by conventional techniques in the Warburg respirometer at $30^{\circ}$. Suitable amounts of the yeast preparations, generally 2-10 mg. dry wt., were suspended in 0.033 m-phosphate buffer ( $\mathrm{pH}$ 6) containing any additional substances as noted in the text. Substrates were added from the side-arm after equilibration to give a! final concentration of either $0.01 \mathrm{~m}$ (for hexoses) or $0.02 \mathrm{~m}$ (for other substrates). In oxygen uptake measurements, $20 \%(\mathrm{w} / \mathrm{v}) \mathrm{KOH}$ was placed in the centre well; for measurements on cyanide inhibition of respiration, this was replaced with appropriate KOH-KCN mixtures (Umbreit, Burris \& Stauffer, 1949).

For cytochrome oxidase assays on heated suspensions, the substrate was 0.02 $\mathrm{M}$ - $p$-phenylenediamine and the vessels contained $0.033 \mathrm{M}$-phosphate

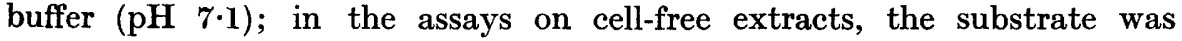
0.02 $\mathrm{M}$-ascorbate and the vessels contained $0.033 \mathrm{M}$-phosphate buffer $(\mathrm{pH} \mathrm{7 \cdot 1})$, $0.01 \mathrm{M}-\mathrm{NaCl}$ and $3 \times 10^{-5} \mathrm{M}$-cytochrome $c$. The recorded values have been corrected for autoxidation of the substrates; in the assays with ascorbate the autoxidation rate was measured by extrapolating to an enzyme concentration of zero from a series of different enzyme concentrations (see Umbreit et al. 1949).

The $Q_{0_{z}}^{\text {air }}$ and $Q_{\mathrm{co}_{3}}^{\mathrm{N}}$, values were calculated for a period of linear activity, generally for the first hour, and are expressed as $\mu \mathrm{l}$. gas/mg. dry wt. yeast/hr. Except where otherwise specified, all $Q_{0}^{\text {alr }}$ and $Q_{0}^{\mathrm{N} \delta_{2}}$, values have been corrected for endogenous values; the trends of the results are not altered by omitting these corrections but the corrected values are felt to be a better expression of the activities studied. The endogenous values did not vary appreciably in the different preparations and, with exceptions indicated in the text, were only a small percentage of the values obtained with added substrate. The endogenous $Q_{0_{3}}^{\text {alr }}$ value was 2-3.5 for organisms grown on the standard glucosecontaining media and 3-5 for those grown on galactose-containing media, while the endogenous $Q_{\mathrm{C}}^{\mathrm{N}}$, value was 0-2 and may be considered negligible.

\section{Determination of cytochrome $\mathrm{c}$}

Quantitative estimation of cytochrome $c$ content in yeast suspensions was made with a microspectroscope assembly (kindly made available by $\mathrm{Dr} \mathbf{W}$. E. van Heyningen). A solution of commercial cytochrome $c$ was used as a standard, and sodium hydrosulphite (dithionite) was added to both suspensions and standard to maintain the cytochrome in the reduced state. 


\section{RESULTS}

Characteristics of organisms grown in the standard glucose and galactose media

Growth. The nature of the sugar added to the basal casein digest+Marmite growth medium influenced both the kinetics of growth and the maximum yields of organisms obtained (Fig. 1). In the presence of glucose, growth began without appreciable delay and the final yield was equivalent to $1 \cdot 1 \mathrm{mg}$. dry wt. organisms/ml. medium. With galactose there was a lag period of about $6 \mathrm{hr}$.,

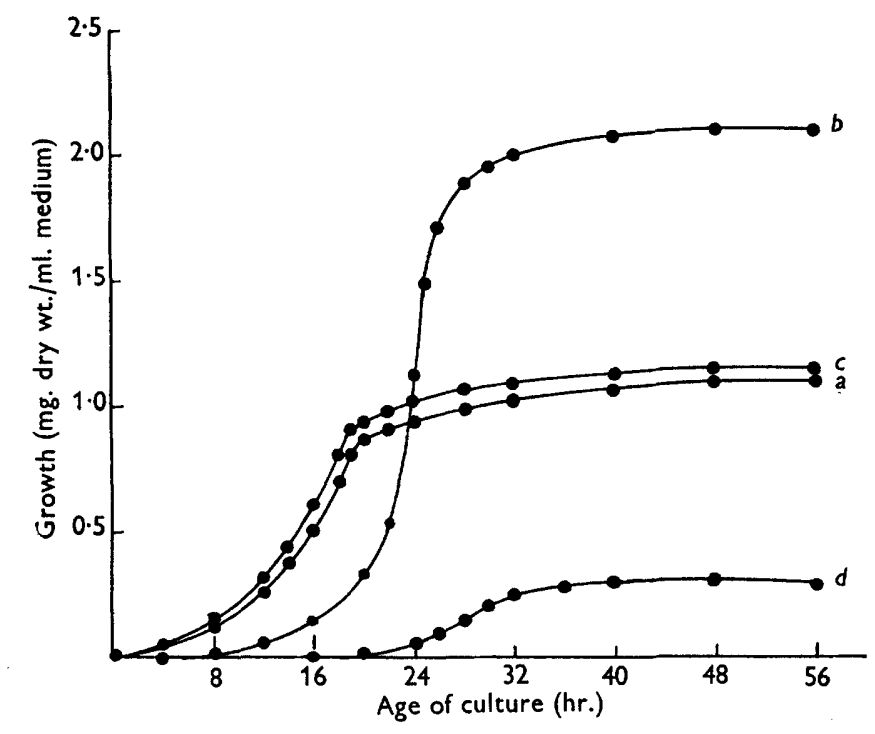

Fig. 1. Effect of sugar in growth medium on growth of Saccharomyces cerevisiae. Unadapted yeast was grown in the basal easein digest + Marmite medium to which was added: (a) $2 \%(\mathrm{w} / \mathrm{v})$ glucose; $(b) 2 \%(\mathrm{w} / \mathrm{v})$ galactose; $(c) 2 \%(\mathrm{w} / \mathrm{v})$ glucose $+2 \%(\mathrm{w} / \mathrm{v})$ galactose ; (d) no sugar added.

reflecting the need for this organism to adapt to utilization of galactose, but the final growth obtained was twice as great as that obtained with the glucose medium. Mixtures of glucose and galactose produced growth curves approximating that obtained with glucose alone, while omission of any added sugar resulted in only poor growth after a long and variable lag period of 18-24 hr.

Oxidation and fermentation of glucose. Organisms growing in the standard casein digest + Marmite medium containing either glucose or galactose were harvested at various ages and their ability to oxidize and ferment glucose was determined. For any given growth time, galactose-grown organisms oxidized glucose much more rapidly than did glucose-grown organisms (Fig. 2a); this difference was of the same magnitude whether or not a correction for endogenous oxygen uptake was made. Except for organisms from very young cultures (12 hr.), galactose-grown organisms also fermented glucose at a greater rate than did the glucose-grown ones (Fig. $2 b$ ).

Since both oxidative and fermentative capacities decreased with age in both 
types of yeast, further experiments in this study were carried out with organisms of the same physiological age, harvested $1 \mathrm{hr}$. before the end of the logarithmic phase of growth. As can be seen from Fig. 1, this age for harvesting was at about $18 \mathrm{hr}$. for glucose-grown organisms and at about $24 \mathrm{hr}$. for galactose-grown organisms. When compared at these equivalent physiological ages, the galactose-grown organisms oxidized glucose $\mathbf{5 \cdot 7}$ times as rapidly as the glucose-grown ones (Fig. $2 a$ ); in a series of ten preparations, the average (corrected) values of $Q_{0_{2}}^{\text {air }}$ (glucose) were $50 \cdot 7( \pm 2 \cdot 8)$ and $8 \cdot 8( \pm 0 \cdot 9)$, respectively. The $Q_{\mathbf{O}_{2}}^{\mathrm{N}}$, (glucose) level was about 150 for both types of organism (Fig. 2b).
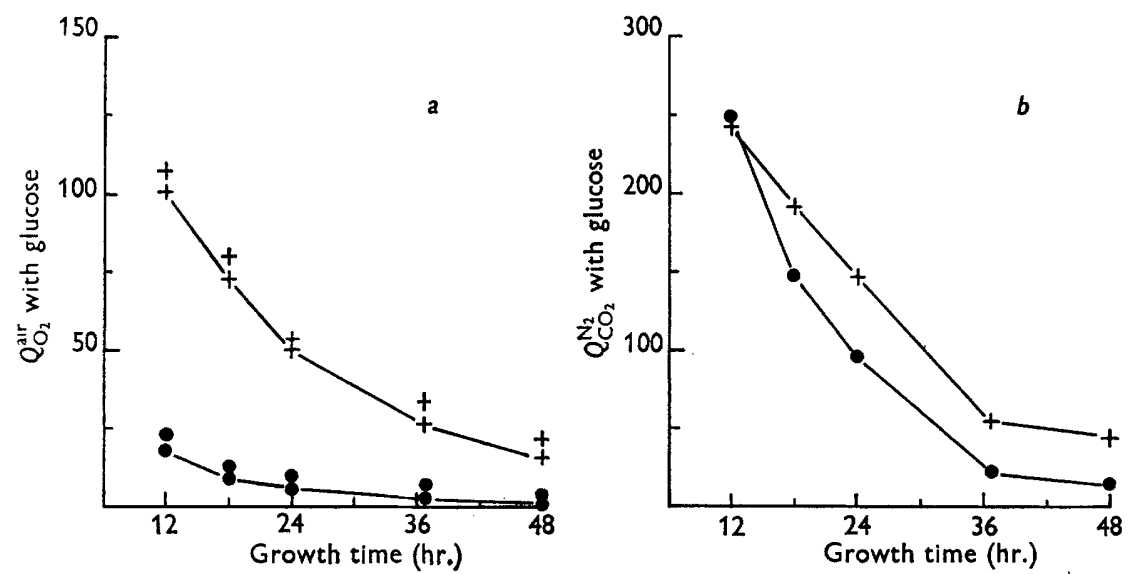

Fig. 2a, b. Effect of age of culture on ability of harvested Saccharomyces cerevisiae to (a) oxidize glucose, and (b) ferment glucose anaerobically. Organisms were harvested at indicated times from standard casein digest + Marmite medium containing either $2 \%(w / v)$ glucose $(-\rightarrow)$ or $2 \%(w / v)$ galactose $(+-+)$ and were assayed manometrically with $0.01 \mathrm{M}$-glucose as substrate. In Fig. $2 a$, the lower of each pair of points represents the activity corrected for endogenous respiration; the upper point is uncorrected.

Oxidation and fermentation of galactose. The unadapted glucose-grown yeast did not metabolize galactose appreciably, while the galactose-grown organisms both oxidized and fermented this sugar (Table 1 ). It is of interest that the

Table 1. Metabolism of glucose and galactose by Saccharomyces cerevisiae grown in media containing either glucose or galactose

\begin{tabular}{|c|c|c|c|}
\hline \multirow[b]{2}{*}{ Assay } & \multicolumn{3}{|c|}{ Growth conditions } \\
\hline & $\begin{array}{c}\text { Glucose } \\
\text { (18 hr.) }\end{array}$ & $\begin{array}{c}\text { Galactose } \\
(24: \mathrm{hr} .)\end{array}$ & $\begin{array}{c}\text { Galactose } \\
(44 \mathrm{hr} .)\end{array}$ \\
\hline$Q_{\mathbf{O}_{\mathbf{g}}}^{\text {air }}$ (glucose) & $9 \cdot 5$ & $52 \cdot 4$ & $17 \cdot 6$ \\
\hline$Q_{O_{1}}^{\text {air }}$ (galactose) & $\mathbf{0}$ & $15 \cdot 8$ & $17 \cdot 9$ \\
\hline$Q_{\mathrm{CO}}^{\mathrm{N}}$ (glucose) & $148 \cdot 0$ & $151 \cdot 0$ & $52 \cdot 0$ \\
\hline$Q_{\mathrm{Co}}^{\mathrm{Ng}}$ (galactose) & $1 \cdot 0$ & $138 \cdot 0$ & $49 \cdot 5$ \\
\hline
\end{tabular}

Organisms were harvested at the times indicated and assayed manometrically with $0.01 \mathrm{M}$-glucose or galactose as substrate. 
$24 \mathrm{hr}$. galactose-grown organisms oxidized galactose at only one-third the rate observed with glucose although both sugars were fermented at similar rates; in older cultures the oxidative rates for the two sugars approached equality. Since, however, the rates of both oxidation and fermentation of glucose were decreasing markedly with age (Fig. 2), it is difficult to deduce evidence for changing metabolic patterns from such data.

Oxidation of other substrates. The high rate of glucose oxidation by the galactose-grown yeast reflected a generally higher level of oxidative activity in these organisms, compared with those grown on glucose. Of the substrates tested, all those attacked by the yeasts were oxidized more rapidly by the galactose-grown organisms (Table 2).

Table 2. Respiration of glucose-grown and galactose-grown Saccharomyces cerevisiae in the presence of various substrates

Harvested organisms were assayed by conventional manometric techniques at $30^{\circ}$ in 0.033 M-phosphate, pH 6.0. Acid substrates were neutralized with sodium hydroxide to pH 6.0 before addition. The endogenous respiratory rate was not subtracted in calculating the $Q_{O_{2}}^{\text {air }}$ values in this table.

$\begin{array}{lcc}\text { Substrate } & \overbrace{\begin{array}{c}\text { Glucose-grown } \\ \text { yeast }\end{array}}^{Q_{0_{2}}^{\text {air }}} \\ \text { None } & 3 \cdot 0 & 4.5 \\ \text { Glucose, } 0.01 \mathrm{M} & 13 \cdot 2 & 54.7 \\ \text { Ethanol, } 0.02 \mathrm{M} & 13 \cdot 3 & 52 \cdot 1 \\ \text { Lactate, } 0.02 \mathrm{M} & 5 \cdot 4 & 31.9 \\ \text { Pyruvate, } 0.02 \mathrm{M} & 3 \cdot 6 & 19 \cdot 2 \\ \text { Acetate, } 0.02 \mathrm{M} & 2 \cdot 6 & 4.5 \\ \text { Succinate, } 0.02 \mathrm{M} & 3 \cdot 0 & 6 \cdot 0 \\ \text { Fructose diphosphate, } 0.01 \mathrm{M} & 2 \cdot 6 & 4.5\end{array}$

There is no evidence that these parallel differences between the two kinds of organism derived from a generally greater permeability of the galactosegrown ones to the substrates. Glucose freely entered both types, as indicated by the same high rates of anaerobic fermentation in both (Fig. $2 b$ ). On the other hand, succinate and fructose diphosphate, the two test substances which are known to be seriously affected by a permeability barrier at the $\mathrm{pH}$ value of the assay system, were not rapidly attacked by either type. Of the other substrates, pyruvate is known to permeate the yeast cell wall, though less readily than at an acid $\mathrm{pH}$ value, and the remaining substances pass freely (see Barron, Ardao \& Hearon, 1951; Eaton \& Klein, 1954).

Electron transport system. The generally higher level of oxidative activity in the galactose-grown organisms suggested a greater capacity of its terminal respiratory system for transport of electrons to oxygen. If grown aerobically, most strains of Saccharomyces cerevisiae develop the cyanide-sensitive cytochrome-cytochrome oxidase system as the major pathway of electron transport (Warburg, 1927; Keilin, 1929). This system also predominated in the yeasts used in the present study, since cyanide $\left(10^{-3} \mathrm{M}\right)$ produced $85-90 \%$ inhibition of glucose oxidation and about $95 \%$ inhibition of lactate oxidation 
by suspensions of both glucose-grown and galactose-grown organisms. The concentration of components of the cytochrome-cytochrome oxidase system in the two kinds of yeast was therefore compared (Table 3).

Table 3. Cytochrome oxidase activity and cytochrome c content of glucose-grown and galactose-grown Saccharomyces cerevisiae

\begin{tabular}{|c|c|c|c|}
\hline \multirow[b]{2}{*}{ Preparation used } & \multirow[b]{2}{*}{ Assay } & \multicolumn{2}{|c|}{ Activity } \\
\hline & & $\begin{array}{l}\text { Glucose- } \\
\text { grown } \\
\text { yeast }\end{array}$ & $\begin{array}{l}\text { Galactose- } \\
\text { grown } \\
\text { yeast }\end{array}$ \\
\hline Heated yeast suspension & $\begin{array}{l}Q_{0}^{\text {air } * \text { (endogenous })} \\
Q_{0_{2}}^{\text {alr }}(p \text {-phenylenediamine })\end{array}$ & $\begin{array}{l}0 \cdot 1 \\
0 \cdot 9\end{array}$ & $\begin{array}{l}0 \cdot 4 \\
5 \cdot 7\end{array}$ \\
\hline Cell-free extract & 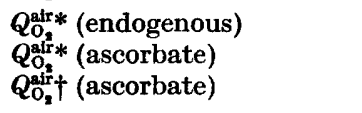 & $\begin{array}{l}0 \\
0 \cdot 9 \\
3 \cdot 0\end{array}$ & $\begin{array}{c}0 \\
9 \cdot 1 \\
26 \cdot 3\end{array}$ \\
\hline Untreated yeast suspension & $\begin{array}{l}\text { Cytochrome } c . \\
(\mu \text { mole/mg. dry wt. })\end{array}$ & $0.64 \times 10^{-4}$ & $1.08 \times 10^{-4}$ \\
\hline
\end{tabular}

The $Q_{0}^{\text {air }}$ values are corrected for autoxidation of substrate but not for endogenous respiration.

${ }^{*} \mu \mathrm{l} . \mathrm{O}_{2} / \mathrm{mg}$. dry wt. of original yeast suspension $/ \mathrm{hr}$.

$\dagger \mu l . \mathrm{O}_{2} / \mathrm{mg}$. dry wt. of cell-free extract $/ \mathrm{hr}$.

Cytochrome oxidase activity was determined manometrically both on heated suspensions with $p$-phenylenediamine as substrate and on cell-free extracts with ascorbate as substrate, as described in Methods. The ratio of activities for galactose-grown against glucose-grown organisms was about 6.5:1 by assay of heated organisms and 10:1 by assay of the cell-free extracts. The activities of the cell-free extracts were calculated both on the basis of dry weight of the original suspensions and on the basis of 'dry weight' of the extracts, determined by drying the material precipitable from the extracts by trichloroacetic acid. The ratio of activities was nearly the same by both methods of calculation, indicating that both cell-free extracts represented approximately the same proportion (about one-third) of the original whole cell substance.

The $Q_{\mathbf{O}_{2}}^{\text {atr }}$ values obtained by either assay fall below the minimum physiological capacity of the cytochrome oxidase system (presumably represented by the $Q_{0_{2}}^{\text {atr }}$ values obtained with glucose or ethanol as substrate). These low activities probably reflect non-optimal conditions of the assay procedures and loss of enzyme activity during preparation of extracts or heated suspensions. However, the fair agreement of the activity ratios obtained by independent assay systems supports the conclusions that the cytochrome oxidase activity of galactose-grown organisms is markedly greater than that of glucose-grown ones.

The cytochrome $c$ content, as determined on suspensions, was only $70 \%$ higher in galactose-grown organisms. This small increase in cytochrome $c$, in contrast to the great increase in cytochrome oxidase activity, may be compared with observations of Slonimski (1955) on anaerobically-grown yeast: exposure to oxygen induced a 200 -fold increase in cytochrome oxidase activity, but only a 20-fold increase in cytochrome $c$ content. 


\section{Adaptive (inductive) nature of the phenomenon}

Two types of experiments were employed to test whether the differences in oxidative capacities between glucose-grown and galactose-grown organisms result from adaptive (inductive) changes or from selection of different strains (or mutants) in the growth media.

First, following seven subcultivations in the standard galactose-containing liquid medium, the harvested organisms had a $Q_{0_{\mathbf{s}}}^{\text {air }}$ (glucose) value of 52, typical of galactose-grown organisms. If after such repeated galactose cultivation the yeast was grown once in the standard glucose medium, the $Q_{\mathrm{O}_{2}}^{\text {air }}$ (glucose) value of harvested organisms was 9 .

Secondly, an inoculum from the stock yeast culture was streaked on agar plates of the same composition as the maintenance medium but with $2 \%(\mathrm{w} / \mathrm{v})$ galactose replacing $0.5 \%(\mathrm{w} / \mathrm{v})$ sucrose as chief carbon source. After growth a single colony was chosen to streak a new plate, and after ten such transfers a single colony was used as inoculum for growth in casein digest + Marmite liquid medium containing $2 \%(\mathrm{w} / \mathrm{v})$ glucose or $2 \%(\mathrm{w} / \mathrm{v})$ galactose. The organisms were harvested and assayed manometrically. In three independent experiments, the organisms thus grown in galactose medium possessed an average $Q_{0_{2}}^{\text {air }}$ (glucose) value of $53 \cdot 2(51 \cdot 2,53 \cdot 6,54 \cdot 9)$; the glucose-grown organisms possessed a $Q_{0_{\mathbf{2}}}^{\text {alr }}$ (glucose) value of $9 \cdot 0(8 \cdot 6,8 \cdot 9,9 \cdot 5)$.

In both types of experiments, therefore, repeated exposure to conditions favouring selection of highly oxidative strains did not alter the oxidative capacity of the galactose-grown yeast, while a single passage through glucosecontaining medium reduced the oxidative level to that normally observed with glucose-grown organisms. The results strongly suggest that the differences in oxidative levels betweeen these glucose-grown and galactose-grown yeasts are adaptive (inductive) in origin.

\section{Factors which affect the differences in growth and oxidative capacity}

Strain of yeast. The differences between glucose-grown and galactose-grown yeast with respect to growth and oxidative capacity were not unique to Saccharomyces cerevisiae strain no. 77, but were also observed with the 'Yeast Foam' strain of $S$. cerevisiae (kindly supplied by Dr P. Slonimski). However, the differences were not as great with the 'Yeast Foam' strain.

Concentration of sugar in the growth medium. The oxidative activity of harvested organisms was markedly decreased when the initial concentration of glucose in the growth medium exceeded a very low optimal concentration, while high initial concentrations of galactose caused a relatively slight decrease of oxidative activity (Table 4). The anaerobic fermentation rates were not appreciably altered by these manipulations. With the lowest concentration of glucose tested, $\mathbf{0 . 5} \mathbf{m g} . / \mathrm{ml}$. growth medium, the organisms possessed a $Q_{0_{2}}^{\text {air }}$ (glucose) value approaching that found with galactose-grown organisms, while with concentrations of $10 \mathrm{mg} . / \mathrm{ml}$. or more, the oxidative rate was less than $20 \%$ of that of galactose-grown organisms. With galactose, increasing the concentration from 1 to $200 \mathrm{mg}$. $/ \mathrm{ml}$. decreased the $Q_{0_{\mathbf{2}}}^{\text {air }}$ (glucose) value of the 
resultant organisms by only about $20 \%$. The sugar concentrations required to produce maximum oxidative activities may be lower than the minimum concentrations employed. However, this possibility could not be tested since appreciably lower concentrations had the same effect as entirely omitting

\section{Table 4. Effect of varying the sugar concentration of the growth medium} on metabolic activity of Saccharomyces cerevisiae

Glucose or galactose was added to the basal casein digest + Marmite medium in the concentrations indicated. Organisms were grown and harvested in the standard manner and assayed manometrically with $0.01 \mathrm{M}$-glucose as substrate.

\begin{tabular}{|c|c|c|c|c|}
\hline \multirow{3}{*}{$\begin{array}{l}\text { Initial concen- } \\
\text { tration of sugar } \\
\text { in growth } \\
\text { medium } \\
(\mathrm{mg} . / \mathrm{ml} .)\end{array}$} & \multicolumn{4}{|c|}{ Activity } \\
\hline & \multicolumn{2}{|c|}{ Glucose-grown yeast } & \multicolumn{2}{|c|}{ Galactose-grown yeast } \\
\hline & $Q_{\mathrm{O}_{2}}^{\mathrm{air}}$ & $Q_{0 \delta_{2}}^{N_{2}}$ & $Q_{0}^{\text {air }}$ & $Q_{\mathrm{CO}_{2}}^{\mathrm{N}}$ \\
\hline $0 \cdot 5$ & $\mathbf{5 2 \cdot 0}$ & 163 & 一 & - \\
\hline $1 \cdot 0$ & $39 \cdot 5$ & 174 & $60 \cdot 9$ & 180 \\
\hline $2 \cdot 0$ & $30 \cdot 1$ & 160 & $59 \cdot 8$ & 162 \\
\hline $10 \cdot 0$ & $10 \cdot 5$ & 153 & - & - \\
\hline $20 \cdot 0$ & $8 \cdot 8$ & 148 & $\mathbf{5 1 \cdot 3}$ & 156 \\
\hline $50 \cdot 0$ & $7 \cdot 9$ & 150 & $49 \cdot 7$ & 160 \\
\hline $200 \cdot 0$ & - & 一 & $50 \cdot 4$ & 163 \\
\hline
\end{tabular}

added sugar from the basal growth medium: there were long lag periods and poor growth (Fig. 1), and the organisms obtained had low metabolic activities (Table 5).

Table 5. Effect of varying the type of sugar in the growth medium on growth and metabolic activity of Saccharomyces cerevisiae

Sugars as indicated were added to the basal casein digest + Marmite growth medium; growth, harvesting and assays were carried out by the standard procedures. The $Q_{0}^{\mathrm{air}}$ and $Q_{0 \mathrm{~N}}^{\mathrm{N}}$, values were obtained with the harvested organisms using $0.01 \mathrm{M}$-glucose as substrate. Growth values represent the levels reached if the cultures were permitted to grow to maximum density. Values given are the average of results from four to ten experiments.

\begin{tabular}{|c|c|c|c|c|}
\hline \multirow{2}{*}{$\begin{array}{l}\text { Sugar added to } \\
\text { growth medium }\end{array}$} & \multicolumn{2}{|c|}{$\begin{array}{c}\text { Activity of } \\
\text { harvested organisms }\end{array}$} & \multirow{2}{*}{$\begin{array}{c}\text { Maximum } \\
\text { growth } \\
\text { (mg./ml.) }\end{array}$} & \multirow{2}{*}{$\begin{array}{c}\text { Increase } \\
\text { in lag } \\
\text { phase* } \\
\text { (hr.) }\end{array}$} \\
\hline & $Q_{\mathrm{O}_{2}}^{\mathrm{air}}$ & $Q_{\mathrm{CO}}^{\mathrm{N} \hat{O}_{2}}$ & & \\
\hline $2 \%(w / v)$ glucose & $8 \cdot 8$ & 148 & $1 \cdot 10$ & (0) \\
\hline $2 \%(w / v)$ galactose & 50.7 & 153 & $2 \cdot 20$ & 6 \\
\hline $\begin{array}{l}2 \%(w / v) \text { glucose }+2 \% \\
(w / v) \text { galactose }\end{array}$ & $14 \cdot 3$ & 135 & $1 \cdot 15$ & 0 \\
\hline $2 \%(w / v)$ fructose & $9 \cdot 0$ & 166 & $1 \cdot 18$ & $\mathbf{0}$ \\
\hline $2 \%(w / v)$ mannose & $15 \cdot 0$ & 161 & $1 \cdot 25$ & 2 \\
\hline None added & $<5$ & $<25$ & $0 \cdot 30$ & $18-24$ \\
\hline
\end{tabular}

* Increase in duration of lag phase over that obtained with glucose.

These results suggest that the relatively low oxidative activity of the glucose-grown organisms derives primarily from an inhibitory effect of glucose on the development of oxidative capacity in the growing organisms, i.e. on the formation of the enzymes involved in oxidative metabolism. However, the 
possibility of an additional stimulatory effect of galactose is not thereby ruled out.

Type of sugar in growth medium. Exploratory experiments showed that the glucose-grown yeast could, without preliminary adaptation, ferment or oxidize fructose and mannose approximately as fast as it did glucose. Yeast hexokinase is known to phosphorylate fructose and mannose readily (Berger, Slein, Colowick \& Cori, 1946) and the phosphorylated derivatives enter the main stream of glucose metabolism. It is therefore significant that when used as growth substrates (Table 5) these sugars produced organisms similar in their low oxidative activities to those grown in glucose medium; in addition, the growth curve and yield of organism with these sugars were similar to those obtained with glucose.

Organisms grown in a mixture of glucose and galactose also were similar in their growth characteristics and low oxidative activity to those grown in glucose alone (Table 5). Apparently, these organisms produced preferentially the balance of enzyme constituents required for the less oxidative metabolic pattern evoked by high concentrations of the normal 'constitutive' substrate, glucose. These glucose + galactose-grown organisms were partially adapted to utilization of galactose at the standard age of harvest $\left(18 \mathrm{hr}\right.$.): the $Q_{\mathrm{O}_{2}}^{\text {air }}$ and $Q_{\mathrm{CO}_{2}}^{\mathrm{N}_{2}}$ values with galactose as substrate were $\mathbf{5 \cdot 4}$ and $7 \cdot 0$, respectively. Adaptation increased with age of culture, e.g. at $24 \mathrm{hr}$. $Q_{\mathrm{CO}_{2}}^{\mathrm{N}_{3}}$ (galactose) was 27 , but the decrease of metabolism activities with age of culture became the more significant factor, e.g. at $24 \mathrm{hr}$. the $Q_{0_{2}}^{\text {air }}$ (galactose) and $Q_{0_{2}}^{\text {atr }}$ (glucose) values, while now nearly equal, had dropped to $4 \cdot 2$ and $5 \cdot 3$, respectively.

Changes in medium during growth. Since the acidity of the environment may determine what type of metabolism develops in a micro-organism (White et al. $1955)$, the $\mathrm{pH}$ value of the glucose and galactose growth media was determined at various ages of culture. The acidity increased in both media in proportion to the amount of growth. At the standard times of harvest the $\mathrm{pH}$ value of the glucose medium was 4.5 and that of the galactose medium, $4 \cdot 2$. This parallel drop of $\mathrm{pH}$ value and lack of gross difference in acidity between the two cultures appears to rule out acidity as a significant factor in the different metabolic patterns of glucose-grown and galactose-grown yeasts.

The decline in the concentration of added sugar in the medium with time was also examined, since exhaustion of hexose might stimulate increased development of oxidative metabolism (Swanson \& Clifton, 1948). The remaining sugar of the growth media was separated by paper chromatography, eluted and assayed by an anthrone method (Koehler, 1952). More than one-fourth of the glucose or galactose initially present remained at the standard ages of harvest, hence the increased oxidative activity of the galactose-grown organisms cannot be attributed to an early exhaustion of galactose from the growth medium.

Composition of the basal growth medium. The difference between the glucosegrown and galactose-grown yeasts with respect to oxidative activity and maximum growth were profoundly affected by altering the composition of the basal growth medium (Table 6 ). For organisms of equivalent physiological ages the 
oxidative activity was similar in galactose-grown organisms harvested from different media (column 6), while the oxidative activity of glucose-grown organisms was greatly altered by change of growth medium (column 3). Variation in the ratio of oxidative activities in the two types of yeast therefore largely reflects the effect of the medium on the inhibition by glucose of oxida-

\title{
Table 6. Influence of composition of growth medium on growth and metabolic activity of Saccharomyces cerevisiae
}

\begin{abstract}
Organisms were grown in the various basal media to which were added either $2 \%(w / v)$ glucose or $2 \%(\mathrm{w} / \mathrm{v})$ galactose ; all media were initially adjusted to $\mathrm{pH} \mathrm{5 \cdot 3}$. The $Q_{\mathrm{air}}^{\mathrm{O}_{2}}$ and $Q_{\mathrm{C} \delta_{2}}^{\mathrm{N}}$ values with glucose as substrate were obtained with organisms harvested at equivalent physiological ages late in the period of logarithmic growth. Growth values represent the levels obtained when the cultures were permitted to grow to maximum density. Values given in this table represent the average of results from three to ten experiments.
\end{abstract}

\begin{tabular}{|c|c|c|c|c|c|c|c|}
\hline \multirow{3}{*}{$\begin{array}{l}\text { Medium } \\
\text { no. } \\
\text { (1) }\end{array}$} & \multirow{3}{*}{$\begin{array}{c}\text { Composition of basal medium } \\
\text { (2) }\end{array}$} & \multicolumn{3}{|c|}{ Glucose-grown yeast } & \multicolumn{3}{|c|}{ Galactose-grown yeast } \\
\hline & & $Q_{\mathrm{O}_{2}}^{\text {air }}$ & $Q_{\mathrm{CO}_{2}}^{\mathrm{N}}$ & $\begin{array}{c}\text { Yield } \\
(\mathrm{mg} \cdot / \mathrm{ml} .)\end{array}$ & $\mathbf{Q}_{\mathrm{O}_{2}}^{\mathrm{air}}$ & $Q_{\mathrm{CO}_{2}}^{\mathrm{N}}$ & $\begin{array}{c}\text { Yield } \\
\mathrm{mg} / \mathrm{ml} .)\end{array}$ \\
\hline & & (3) & $(4)$ & (5) & $(6)$ & $(7)$ & (8) \\
\hline 1 & $\begin{array}{l}\text { Casein digest }+0.05 \%(w / v) \\
\text { Marmite }\end{array}$ & $8 \cdot 8$ & 148 & $1 \cdot 10$ & $50 \cdot 7$ & 153 & $2 \cdot 20$ \\
\hline 2 & $\begin{array}{l}\text { Casein digest }+0.025 \%(w / v) \\
\text { Marmite }\end{array}$ & $6 \cdot 5$ & 166 & $0 \cdot 38$ & $43 \cdot 7$ & 163 & $0 \cdot 78$ \\
\hline 3 & $\begin{array}{l}\text { Casein digest }+0 \cdot 2 \%(w / v) \\
\text { Marmite }\end{array}$ & $15 \cdot 8$ & $174 *$ & 1.93 & $56 \cdot 8$ & $164 *$ & $3 \cdot 44$ \\
\hline 4 & $\begin{array}{l}\text { Casein digest }+0.5 \%(w / v) \\
\text { Marmite }\end{array}$ & $45 \cdot 6$ & $250 *$ & $5 \cdot 28$ & $73 \cdot 7$ & $175^{*}$ & $5 \cdot 32$ \\
\hline 5 & $\begin{array}{l}0.05 \%(w / v) \text { Marmite }+ \\
0.1 \mathrm{M}-\text { phosphate }\end{array}$ & $36 \cdot 3$ & 165 & $0 \cdot 58$ & $42 \cdot 7$ & 157 & $0 \cdot 65$ \\
\hline 6 & $\begin{array}{l}0.4 \%(\mathrm{w} / \mathrm{v}) \mathrm{NH}_{4} \mathrm{Cl}+0.05 \% \\
(\mathrm{w} / \mathrm{v}) \text { Marmite }+0.1 \mathrm{M}- \\
\text { phosphate }\end{array}$ & $28 \cdot 2$ & 183 & 0.65 & $67 \cdot 3$ & 191 & $0 \cdot 81$ \\
\hline 7 & Chemically defined & $22 \cdot 4$ & $215^{*}$ & $1 \cdot 99$ & $55 \cdot 4$ & $243 *$ & $1 \cdot 79$ \\
\hline 8 & $\begin{array}{l}\text { Yeast extract-malt } \\
\text { extract-salts }\end{array}$ & $72 \cdot 9$ & 195 & $11 \cdot 0$ & 74.7 & 163 & $11 \cdot 5$ \\
\hline
\end{tabular}

tive enzyme formation. The maximum growth for both glucose-grown and galactose-grown organisms varied with the different media (columns 5 and 8 , respectively), but variation in the relative growth of the two types again reflects the influence of the medium on the inhibitory effect of glucose. The anaerobic fermentation rate was of the same order of magnitude in both types for all growth media tested (columns 4 and 6 , respectively). This constancy of fermentative capacity tends to confirm that the various yeast preparations were of comparable physiological ages.

Of various basal thedia examined, the most marked differences between glucose-grown and galactose-grown organisms were observed with the standard casein digest + Marmite medium; this medium was consequently used as a basis for the experiments reported in this paper. The results of varying the 
concentration of Marmite (media 2, 3, 4) from that in the standard basal medium (medium 1) indicate that an increased Marmite concentration reduces the differences in oxidative activity. Since the Marmite concentration was the limiting factor in the amount of growth obtained, attempts to increase the inhibitory effect of glucose by drastic decrease of Marmite concentration proved impractical.

Omission of casein digest (medium 5) from the standard basal growth medium also resulted in glucose-grown organisms with maximum growth and oxidative activity approaching the levels found in galactose-grown ones. These results suggest that the presence of casein digest permits or potentiates the appearance of the differences between the two types of organism. The phosphate was added to medium 5 to provide buffering capacity; it had no specific effect, as indicated by the fact that addition of $0.1 \mathrm{M}$-phosphate to the standard growth medium (results not tabulated) produced no significant alterations in metabolic activities or growth.

To test further the effects of varying the major nitrogenous constituents, casein digest was replaced by ammonium chloride (medium 6) or ammonium sulphate was used as sole major nitrogen source (medium 7). In the latter case, the chemically defined medium contained, per litre, $2 \mathrm{~g}$. $\left(\mathrm{NH}_{4}\right)_{2} \mathrm{SO}_{4}$, $7 \cdot 5$ g. $\mathrm{KH}_{2} \mathrm{PO}_{4}, 0.5 \mathrm{~g} . \mathrm{MgSO}_{4} \cdot 7 \mathrm{H}_{2} \mathrm{O}, 0 \cdot 15 \mathrm{~g} . \mathrm{CaCl}_{2}, 2 \cdot 8 \mathrm{mg} . \mathrm{FeSO}_{4}, 0 \cdot 4 \mathrm{mg}$. thiamine, $5 \mathrm{mg}$. inositol, $4 \mathrm{mg}$. biotin, $0 \cdot 4 \mathrm{mg}$. pantothenate and $0 \cdot 14 \mathrm{mg}$. $p$-aminobenzoic acid. With either medium, a partial decrease of the glucose inhibition of oxidative activity was obtained, while the maximum growth obtained was nearly the same for glucose-grown and galactose-grown organisms.

The fact that the differences between glucose-grown and galactose-grown organisms were least evident when Marmite was the major nitrogenous component of the growth medium suggests that a balance of substances in the growth medium which resembles the composition of the yeast aids in suppressing the inhibitory effects of glucose.

For comparison, the yeast was also grown in a complex medium (medium 8) identical with that used for the maintenance-agar slopes except for omission of agar and substitution of $2 \%(\mathrm{w} / \mathrm{v})$ glucose or $2 \%(\mathrm{w} / \mathrm{v})$ galactose for $0.5 \%$ $(w / v)$ sucrose. This rich medium, on which the organisms had been maintained for a long period, produced high yields of yeast and high oxidative activity, with no appreciable differences between glucose-grown and galactose-grown organisms in these respects.

\section{DISCUSSION}

The ultimate mechanism by which glucose inhibits the development of oxidative capacity with this Saccharomyces cerevisiae strain is not certain, but several possible factors suggest themselves. First, the results obtained by varying the nature of the sugar present in the growth medium (Tables) indicate that oxidative pathways are relatively little developed in the presence of high concentrations of a sugar readily and immediately fermentable without need for preliminary adaptation. Slonimski (1955) found that high concentrations of 
glucose result in a decreased rate of oxygen-induced formation of certain oxidative enzymes in non-proliferating yeast suspensions; this retardation was associated with a heightened aerobic fermentation rate. Glucose is known to inhibit the formation of a number of enzymes in various organisms (Epps \& Gale, 1942). In at least some instances, this glucose effect may be interpreted as a homœostatic mechanism whereby products formed by metabolism of glucose by 'constitutive' enzyme systems can inhibit the formation of 'adaptive' (inducible) enzymes whose activity would merely increase the metabolic pool of these products (Neidhardt, 1956). Glucose inhibition of oxidative enzyme formation in yeast may similarly reflect an intracellular regulatory mechanism; the 'constitutive' enzyme systems readily fill the energy requirements of the organism by fermentative breakdown of glucose when this sugar is present, and the presence of this metabolic energy pool may partially inhibit the formation of 'adaptive' energy-yielding oxidative enzyme systems.

Secondly, the results obtained by varying the composition of the growth medium (Table 6) suggest that glucose inhibition may involve depletion or imbalance of essential constituents required for formation of oxidative enzymes. Such deficiencies may result from increased utilization of essential components for other purposes or in other reactions not as prominent in a more oxidative metabolic milieu. The synthesis of enzymic protein requires the presence of a complete array of the component amino acids in sufficient quantity (Spiegelman \& Halvorson, 1953), and for optimal utilization by the organism the various amino acids must be presented in correct proportions (Almquist, 1953). Various other substances, including nucleic acids, are also essential components of the protein synthesis mechanism (Gale \& Folkes, 1955).

The reasons for the differences between glucose-grown and galactose-grown organisms reported here are obscure. Gross differences of $\mathrm{pH}$ value in the media during growth or an early depletion of galactose appear to be ruled out as significant factors in causing these differences. Further, organisms grown in glucose + galactose mixtures possess low oxidative activity and give a yield of organisms characteristic of glucose-grown ones (Table 5), despite their ability to metabolize galactose. It therefore seems improbable that galactose or some metabolic derivative of galactose required for essential structural or functional roles exerts a specific stimulatory effect on development of oxidative enzyme activity. The apparent stimulatory effect of galactose appears rather to arise from a relative lack of the glucose type of inhibition. The organism studied must adapt to utilization of galactose and then actively maintain the adaptive enzyme system; the consequent lower facility and capacity for fermenting this substrate, particularly in newly adapting cultures, may permit development of efficient oxidative pathways for more complete utilization of the available supply of substrates for energy production. Galactose may also evoke development of an alternate oxidative pathway perhaps characteristic of galactose metabolism but also utilizable by glucose in the adapted yeast; however, no direct evidence for such a pathway has been obtained. 
The author wishes to express his gratitude to Professor D. D. Woods for his helpful advice and kind encouragement. This work was carried out during the tenure of a Public Health Service Research Fellowship from the National Institutes of Health of the United States.

\section{REFERENCES}

Almquist, H. J. (1953). Principles of amino acid balance. Arch. Biochem. Biophys. 46, 250 .

Barron, E. S. G., Ardao, M. I. \& Hearon, M. (1951). Regulatory mechanisms of cellular respiration. III. Enzyme distribution in the cell. Its influence on the metabolism of pyruvic acid by bakers' yeast. J. gen. Physiol. 34, 211.

Berger, L., Slein, M. W., Colowick, S. P. \& Cori, C. F. (1946). Isolation of hexokinase from bakers' yeast. J. gen. Physiol. 29, 379.

Caputto, R., Leloir, L. F., Cardini, C. E. \& Paladini, A. C. (1950). Isolation of the coenzyme of the galactose phosphate-glucose phosphate transformation. J. biol. Chem. 184, 333.

Cole, S. W. \& Onslow, H. (1916). On a substitute for peptone and a standard nutrient medium for bacteriological purposes. Lancet, ii, 9.

Eaton, N. R. \& Klein, H. P. (1954). The oxidation of glucose and acetate by Saccharomyces cerevisiae. J. Bact. 68, 110.

EPPS, H. M. R. \& GALE, E. F. (1942). The influence of the presence of glucose during growth on the enzymic activities of Escherichia coli. Comparison of the effect with that produced by fermentation acids. Biochem. J. 36, 619 .

Gale, E. F. \& FolkEs, J. (1955). The assimilation of amino acids. 21. The effect of nucleic acid on the development of certain enzymic activities in disrupted staphylococcal cells. Biochem. J. 59, 675 .

Keilin, D. (1929). Cytochromes and respiratory pigments. Proc. Roy. Soc. B, 104, 206.

KoEHLER, L. H. (1952). Differentiation of carbohydrates by anthrone reaction rate and color intensity. Analyt. Chem. 24, 1576.

MrckLe, H. (1948). Tissue disintegrator. J. R. micr. Soc. 68, 10.

Monod, J. (1942). Recherches sur la croissance des cultures bactériennes. Paris: Hermann.

Monod, J., Cohen-Bazire, G. \& Cohn, M. (1951). Sur la biosynthèse de la $\beta$-galactosidase (lactase) chez Escherichia coli. La spécificité de l'induction. Biochim. biophys. Acta, 7, 585.

NeIDHARDT, F. (1956). The effect of glucose on the induced biosynthesis of bacterial enzymes. Ph.D. Thesis, Harvard University.

Shefrner, A. L. \& Lindegren, C. C. (1952). Adaptation to the prefermentative oxidation of galactose. J. Bact. 64, 423 .

Slonimski, P. (1955). Adaptation respiratoire: développement du système hémoprotéique induit par l'oxygène. Proc. IIIrd Int. Congr. Biochem. Brussels, p. 242. Ed. Liébecq, C. New York: Academic Press Inc.

Spiegelman, S. J. (1946). Nuclear and cytoplasmic factors controlling enzymatic constitution. Cold Spr. Harb. Symp. quant. Biol. 11, 256.

Spiegelman, S. J. \& Halvorson, H. O. (1953). The nature of the precursor in the induced synthesis of enzymes. Adaptation in Micro-organisms. Symp. Soc. Gen. Microbiol. 3, 98.

Stephenson, M. \& Yudkin, J. (1936). Galactozymase considered as an adaptive enzyme. Biochem. J. 30, 506.

Stritrmatter, C. F. (1955). Effect of growth medium on oxidative activity in Saccharomyces cerevisiae. J. gen. Microbiol. 13, xiii. 
Swanson, W. H. \& ChrFton, C. E. (1948). Growth and assimilation in cultures of Saccharomyces cerevisiae. J. Bact. 56, 115.

Trucco, R. E., Caputto, R., Leloir, L. F. \& Mittelman, N. (1948). Galactokinase. Arch. Biochem. 18, 137.

Umbreit, W. W., Burris, R. H. \& Stauffer, J. F. (1949). Manometric Techniques and Tissue Metabolism. Minneapolis, Minnesota, U.S.A.: Burgess Publishing Co.

Warburg, O. (1927). Über die Wirkung von Kohlenoxyd und Stickoxyd auf Atmung und Gärung. Biochem. Z. 189, 354.

White, A. G. C., Steele, R. H. \& Pierce, W. A., Jr. (1955). The effect of $\mathrm{pH}$ on the fermentation of glucose and galactose by Streptococcus pyogenes. J. Bact. 70, 82 .

(Received 8 August 1956) 